\title{
COAL OPERATOR MINING FACTS - 2005
}

\section{Mining Operations}

In 2005, a total of 2,063 coal mining operations reported employment to the Mine S afety and Health Administration (MSHA). Coal $\mathrm{m}$ ines com prised $14.1 \%$ of all mining operations.

- Bituminous $m$ ines comprised $92.6 \%(n=1,911)$ and anthracite $m$ ines $7.4 \%(n=152)$ of coa 1 mining operations.

- Approximately $70 \%$ of all coal mines were located in three states: Ken tucky $(28.0 \%)$, W est Virginia (21.8\%), and Pennsylvania (20.6\%).

\section{Employees}

A total of 78,281 employees, ${ }^{1}$ corresponding to 87,184 full-time equivalent (FTE) ${ }^{2}$ employees, were reported by coal mine operators to MSHA.

- Within the $\mathrm{m}$ ining sectors, ${ }^{3}$ coal operators comprised $30.2 \%$ of all employee hours reported.

- Underground work locations accounted for $46.4 \%$ of c oal em ployee hours, while surface work locations accounted for $53.6 \%{ }^{4}$

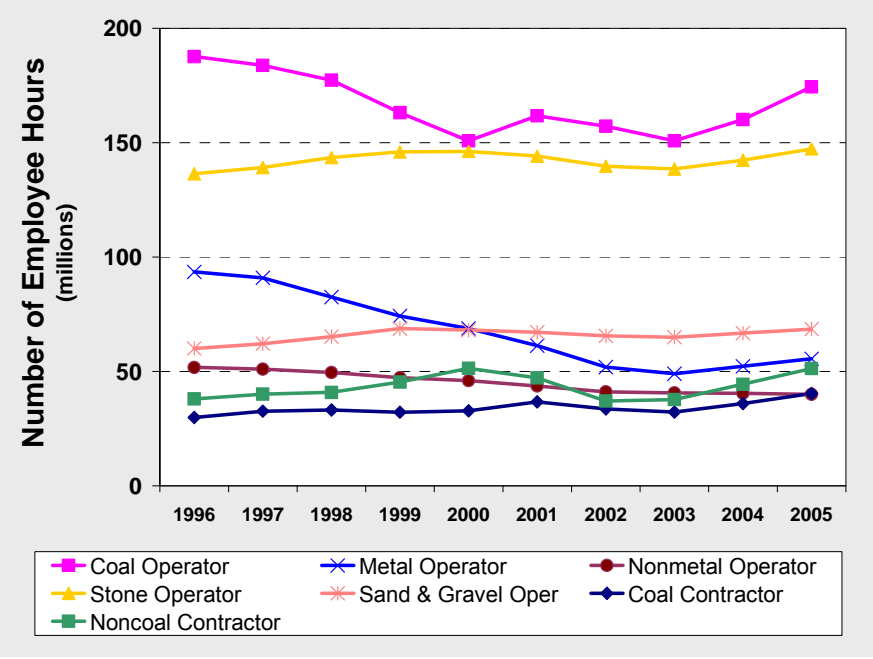

\section{Fatalities}

Seventeen (17) occupati onal $\mathrm{f}$ atalities o ccurred among coal operator employees in 2005, compared to 23 in 2004.

- Fatalities am ong coal operator em ployees accounted for $29.8 \%$ of all mining fatalities.

- The coal operator fatality rate was 19.5 fatalities per 100,000 FTE e mployees. The underground fatality rate was $34.6(n=14)$ com pared to a rate of $6.4(n=3)$ for surface work locations.

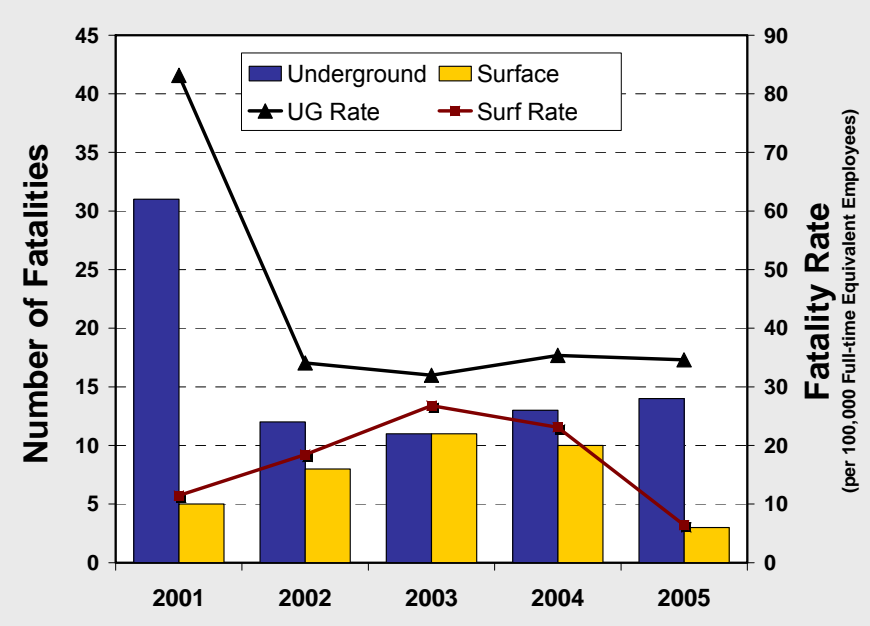

\section{Nonfatal Lost-time Injuries}

There were 3,062 nonfatal lost-tim e injuries $\quad(2,234$ at underground and 828 at surface work locations) among coal operator employees occurring at a rate of 3.5 injuries per $100 \quad$ FTE employees. These injuries resulted in 197,867 days lost ${ }^{5}$ from work, comprising nearly $43.0 \%$ of days lost across all mining sectors.

- The underground nonfatal lo st-time injury rate was greater than th e surface inju ry rate (5.5 vs. 1.8 per 100 FTE workers).

- The most frequent classi fication of nonfatal losttime injuries f or coal opera tor em ployees involved handling materials $(n=886 ; 28.9 \%)$.

- Sprains and str ains we re the $m$ ost $f$ requently reported nature of injury $(n=1,323 ; 43.2 \%)$.

- The back was the $\mathrm{m}$ ost frequently reported part of the body injured $(\mathrm{n}=602 ; 19.7 \%)$ and accounted for 39,918 days lost from work.

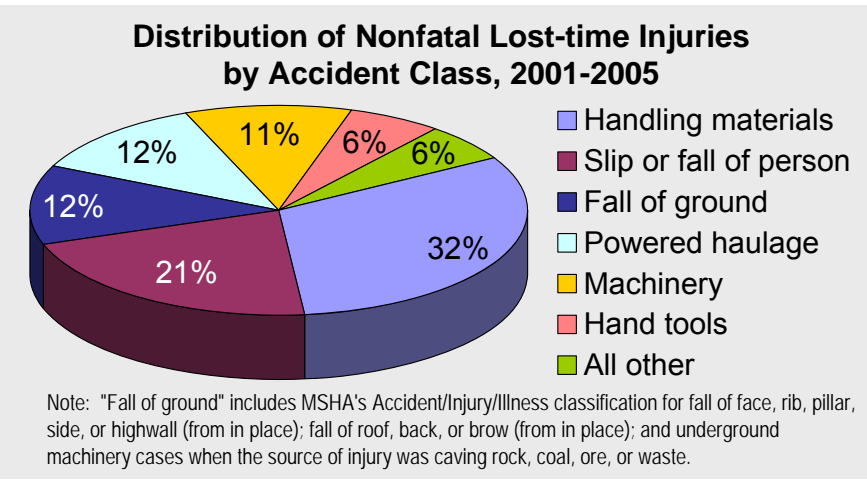




\section{Mining Characteristics, 2005}

\begin{tabular}{|c|c|c|c|c|c|c|}
\hline $\begin{array}{l}\text { Commodity and } \\
\text { Type of Employer }\end{array}$ & $\begin{array}{l}\text { No. of } \\
\text { Mines }\end{array}$ & $\begin{array}{c}\text { No. of } \\
\text { Companies }\end{array}$ & $\begin{array}{c}\text { No. of } \\
\text { Employees }^{1}\end{array}$ & $\begin{array}{l}\text { No. of FTE } \\
\text { Employees }^{2}\end{array}$ & $\begin{array}{l}\text { Fatality } \\
\text { Rate }\end{array}$ & $\begin{array}{l}\text { Nonfatal } \\
\text { Lost-time } \\
\text { Injury Rate }\end{array}$ \\
\hline Coal Operator & 2,063 & -- & 78,281 & 87,184 & 19.5 & 3.5 \\
\hline Metal Operator & 263 & -- & 26,442 & 27,773 & 18.0 & 2.4 \\
\hline Nonmetal Operator & 739 & -- & 19,678 & 20,014 & 20.0 & 2.5 \\
\hline Stone Operator & 4,490 & -- & 69,759 & 73,650 & 20.4 & 3.1 \\
\hline Sand and Gravel Operator & 7,111 & -- & 37,705 & 34,258 & 26.3 & 2.5 \\
\hline Operator Total & 14,666 & -- & 231,865 & 242,879 & 20.6 & 3.0 \\
\hline Coal Contractor & -- & 2,503 & 32,639 & 20,136 & 24.8 & 2.7 \\
\hline Noncoal Contractor & -- & 4,297 & 46,623 & 25,590 & 7.8 & 1.6 \\
\hline Contractor Total & -- & 6,800 & 79,262 & 45,726 & 15.3 & 2.1 \\
\hline TOTAL & & & 311,127 & 288,605 & 19.8 & 2.9 \\
\hline
\end{tabular}

Fatality rates were computed per 100,000 FTE employees. Nonfatal lost-time injury rates were computed per 100 FTE employees.

Data source: Publicly released files of employment and accident/injury/illness data collected by MSHA under 30 CFR 50.

Notes: All analyses exclude office employees, except for the total number of mining operations. Analyses of fatalities exclude all individuals under 17 years of age and all individuals who were not classified as employees of a mining operator or mining contractor. Further statistical methodology is available on the NIOSH Internet [http://www.cdc.gov/niosh/mining/statistics/method.htm].

${ }^{1}$ Number of employees is the average number of persons working at individual establishments during calendar quarters of active operations.

${ }^{2}$ Full-time equivalent employees were computed using reported employee hours $(2,000$ hours $=1$ FTE).

${ }^{3}$ Mining sectors: coal operators, metal operators, nonmetal operators, stone operators, sand and gravel operators, coal contractors, and no ncoal contractors.

${ }^{4}$ Surface work locations include surface operations at underground mines (surface shops and yards, tipple physically located at the mine site), surface operations (strip or open pit mines including associated shops and yards), auger mining operations, culm banks (reworking of mine dumps or refuse pile), dredge (mining operations conducted from a platform floating on water), independent shops and yards not associated with a specific mine, and mill or preparation plant.

${ }^{5}$ Includes actual days away from work and/or days of restricted work activity. For permanently disabling injuries only, statutory days charged by MSHA were used if they exceeded the total lost workdays.

To receive NIOSH documents or for more information about occupational safety and health topics, contact $\mathrm{NIOSH}$ at

1-800-CDC-INFO (1-800-232-4636)

1-888-232-6348 (TTY)

e-mail: cdcinfo@cdc.gov

or visit the NIOSH Web site at http://www.cdc.gov/niosh

DHHS (NIOSH) Publication No. 2008-150

SAFER • HEALTHIER • PEOPLE ${ }^{\text {TM }}$ 